\title{
Topographic influence on landslides characteristics and implication for risk management in upper Manafwa catchment, Mt Elgon Uganda
}

\author{
B. R. Nakileza* (1) and S. Nedala
}

\begin{abstract}
This study aimed to characterize the topographic effect on landslides attributes and explore the implications on risk management in a tropical mountainous environment. A database was constructed based on landslide inventory from field surveys supplemented by desk research. The topographic parameters were derived from STRM DEM of a $30 \mathrm{~m}$ resolution for the study area. The analysis of the data was conducted in Arc GIS 10.5 environment. The relationship between landslides and topographic conditioning factors was analysed using the Frequency Ratio model. Results revealed that most landslides were distributed within the altitudinal range of 1500 to $1800 \mathrm{~m}$ a.s.l. on moderately steep slopes $\left(15^{\circ}-20^{\circ}\right)$ in concave curvatures (hollows). Shallow slides mainly debris flows and debris slides were predominant. Most slope failures were initiated on mid to upper slope positions in either new or old scars. Some runout depositions of large slides ended in streams thus undermining water quality. The findings on topographic parameters have implications and yet landslide risk management by the local population was generally inadequate. Any efforts toward effective landslide risk management should prioritise greening the sensitive topographic hollows and old scars particularly on mid to upper slope positions.
\end{abstract}

Keywords: Landslides, Risk implications, Topographic parameters

\section{Introduction}

Landslides have been described as the most significant damaging events in mountainous regions of the world. Mountainous areas are vulnerable to mass movements due to preparatory/conditional and triggering causal factors. Triggering causal factors (e.g. rainfall, tremors and land use) are external stimuli responsible for the actual initiation of mass movements. Whereas the conditional factors such as geology, weathering, soils, topography are responsible for inducing slope instability. Anthropogenic activities in mountainous regions commonly cause the formation of unstable areas in the earth material on hill slopes (Nefeslioglu et al. 2011). Human activities

\footnotetext{
*Correspondence: nakilezabob@gmail.com

Department of Environmental Management, Makerere University, P.O Box 7062, Kampala, Uganda
}

\section{Springer Open}

such as deforestation has been singled out as a key preparatory factor for recent, shallow landslides $(>3 \mathrm{~m}$ deep) in one study area in Ethiopia by removal of the stabilizing forest vegetation (Broothaerts et al. 2012).

Landslides are increasingly a common occurrence in mountains leading to destruction of property and causing fatalities and injuries in many parts of the developing world particularly in Africa. In Africa various authors have reported landslide problems in highland and mountainous environments, for instance in Kenya (Davies 1996; Ngecu and Ichang 1999; Westerberg and Christiansson 1999; Mwaniki et al. 2015), Cameroun (Ayonghe and Ntasin 2003; Zogning et al. 2007; Nguimbous-Kouoh and Manguelle-Dicoum 2010), Rwanda (Bizimana 2015), Tanzania (Temple and Rapp 1972; Kimaro et al. 2000), Democratic republic of Congo

(c) The Author(s). 2020 Open Access This article is licensed under a Creative Commons Attribution 4.0 International License, which permits use, sharing, adaptation, distribution and reproduction in any medium or format, as long as you give appropriate credit to the original author(s) and the source, provide a link to the Creative Commons licence, and indicate if changes were made. The images or other third party material in this article are included in the article's Creative Commons licence, unless indicated otherwise in a credit line to the material. If material is not included in the article's Creative Commons licence and your intended use is not permitted by statutory regulation or exceeds the permitted use, you will need to obtain permission directly from the copyright holder. To view a copy of this licence, visit http://creativecommons.org/licenses/by/4.0/. 
(Monsieurs et al. 2017; Depicker et al. 2018; Ethiopia (Broothaerts et al. 2012), and South Africa (Gupta 2001) and Uganda (Mertens et al. 2016). Despite the increasing and widespread landslide occurrence in East Africa, there is still limited research (Broothaerts et al. 2012). Knapen et al. (2006) and Broothaerts et al. (2012) indicate that the most important preconditions for landslides in East Africa highlands are steep slopes, high annual rainfall and deep weathered soils with high clay content thus low shear resistance.

In Uganda, landslides have received wider reporting in various media since 1997/8. Subsequent landslide events after this period have caused numerous fatality, injuries, loss of ecosystem services and infrastructure such as buildings, bridges, schools among others. The worst event was in 2010 when over 350 lives were lost in the mudflow and debris slides in Nametsi in Bududa district. Since then numerous studies (e.g. Kitutu et al. 2011; Mugagga et al. 2012) have investigated different aspects of causes, impacts and human response. Based on the literature of the studies in Uganda (e.g. Bagoora, 1993; Knapen et al. 2006; Bamutaze 2019; Nseka et al., 2019) limited focus has been on quantitative analysis of topographic influence on the dynamics of the landslides over space and time. The selected catchment for this study, the upper Manafwa, has experienced a number of landslides but few studies undertaken (Kitutu 2010; Mugagga et al., 2012; Knapen et al., 2006; Claessens et al. 2007; Ngecu et al., 2004) have concentrated on the impacts, causes such as rain fall as a triggering factor and soils. Knapen et al. (2006) observed that steep, plan concave slope segments at a certain distance from the water divide and oriented to the dominant rainfall direction (north to northeast) are the most sensitive to mass movement throughout the study area. Identifying areas with higher risk of landslides requires evaluation of the distribution and frequency of historical landslides (Silalahi et al. 2019). Topography, which is a major land surface characteristic constituting a key pre-condition/ factor in landslide occurrence, needs to be further investigated to guide planning and risk management. Nugraha et al. (2015) argued that land surface (geomorphometric) characteristics, have a significant relationship with the landslide distribution. They further noted that in the Tinalah watershed, for instance, the landslide occurrence coincides mostly with an elevation of higher than 400 m.a.s.l., a slope of $20^{\circ}$, an east-to-west slope direction, and a flat curvature. However, according to Dahl et al. (2011) discriminant function analysis shows that preparatory factors responsible for spatial debris-slide distribution are aspect, slope angle, stream density, plan curvature and altitude, while influence of lithology, dip, profile curvature and differences in infield/outfield areas are negligible. Thus, overall there is still lack of consensus on the topographic factors underpinning landslide distribution. In this study we focused on how the distribution of landslides are shaped by the topographic attributes basing on a case study of the upper Manafwa catchment on the slopes of Mt. Elgon. Fernandes et al. (2004) and Broothaerts et al. (2012) among others have emphasized the role of investigating topographic influence. According to Giuseppe et al. (2016) slope stability is affected by: (i) a decrease in soil suction throughout the whole catchment during a rainfall event; and (ii) by higher water pressures that build up at concave locations, where water is topographically driven through saturated subsurface flows.

The objectives of this study were to (i) analyse the spatial-temporal pattern of landslides that have majorly occurred between 1900 to 2019 (ii) characterize the landslides in relation to varied topographic units during this period and (iii) examine the implications for landslide risk management in the area. This catchmentbased study intended to unravel the dynamics to inform larger and/or regional scale studies (e.g. Afrislide project reported by Kervyn et al. 2015) and for contributing to the current debate on the realization of SDGs 15 and Sendai DRR agenda target 1, 2 and 7 at local level. As stressed by Anderson et al. (2011) such local scale studies can also effectively inform strategies for landslide risk reduction. Besides, the study will inform future attempts to evaluate potential conditioning factors. As pointed out by Soeters and Van Westen 1996 cited in Nefeslioglu et al. (2011) to evaluate potential conditioning factors, the types of failure, activity characteristics and spatial distributions of the movements must first be identified. The selected study area as explained below presents unique topographic characteristics (ruggedness, slope steepness, plan), high population density and relatively higher landslide occurrences which therefore merits focused investigation.

\section{Geographical setting}

This study focused on a major landslide hotspot sub catchment located within the upper part of the Manafwa catchment, on the slopes of Mt Elgon in Uganda (Fig. 1). The sub catchment, majorly drained by the Upper part of R. Manafwa and main tributaries of rivers Tsume and Lukuse, occupies about $166.02 \mathrm{~km}^{2}$. The area experiences varied types of shallow and deep landslides involving largely soil and rock materials.

The sub catchment has got a high stream density due to many streams draining it and high rainfall received. Annual rainfall ranges from $1000 \mathrm{~mm}$ to $1600 \mathrm{~mm}$. Moderate to intense rains are reported in the area. On 


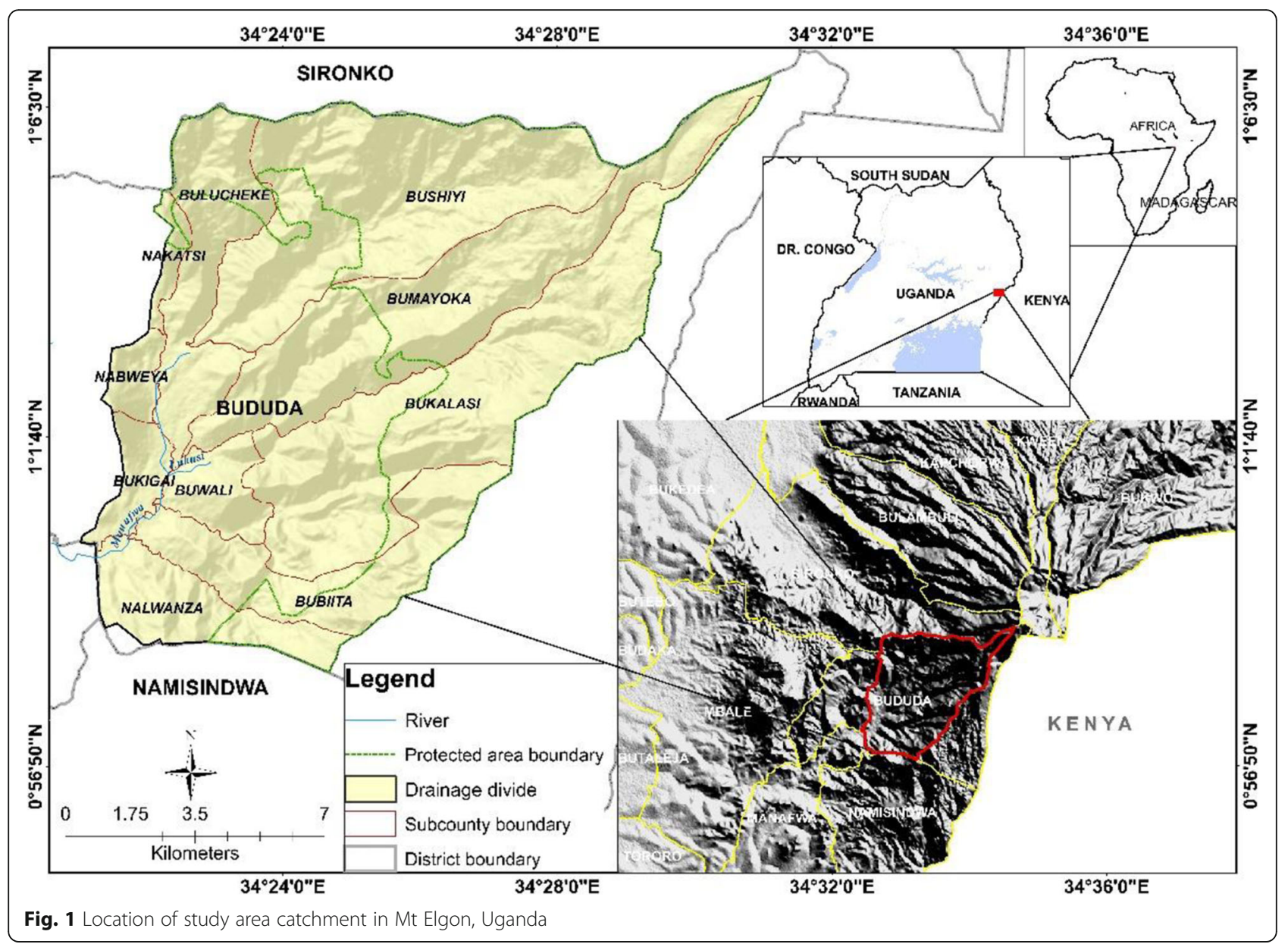

the previous and the very day of the recent landslide occurrence (4th June 2019), moderately heavy rainfall (Fig. 2) was recorded in the eastern part of Bududa district in the sub counties of Buwali, Bukalasi and Bubita.
In general, the altitude of the area lies within a range of $1200 \mathrm{~m}$ to $2900 \mathrm{~m}$ above sea level. It is largely underlain by the basement complex and volcanic rocks (conglomerates and agglomerates) with isolated plugs and dikes such as Nusu. The study area occupying the lower

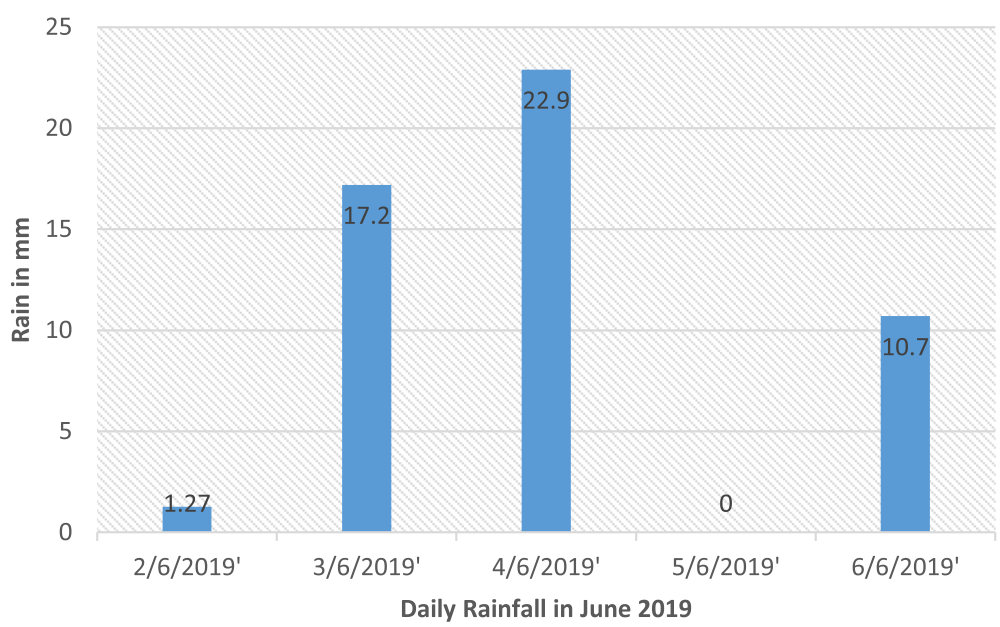

Fig. 2 Rainfall recording, at Bulucheke secondary school, before and after the date of landslide on 4th June 2019 in Bududa 
Elgon Volcanic slopes has been subjected to long time sculpturing by rivers, streams, mass movements and erosion processes acting on varied geology (basement complex, volcanic rocks) hence the observed steeper rectilinear and sharply dissected slopes, valleys and cliffs. The main soil types in the area include luvisols, feralsols, nitosols and leptosols. Major land use is agricultural with dominant crops grown including a mix of coffee and bananas, and a range of horticultural crops (onions, cabbages, tomatoes) on annual crop lands. The area has a high population and dense settlements spread on the hillslopes, crests and valleys. Due to high population pressure there is limited land left uncultivated even on fragile slopes. The upper part of the sub catchment is under forest cover and the management of the Uganda Wildlife Authority. The portion of the forest adjacent the boundary was disturbed in the past due to deforestation for agricultural purposes but is now under recovery. This previously encroached forested portion tends to often experience slope failures probably because of reduced soil cohesion on sloping landscape.

\section{Materials and methods}

\section{Field studies}

A field survey was undertaken in the sub catchment aimed at mapping all the recent and historical scars of the landslides. A GPS (Garmin 60sx) was used to georeference and track the observed landslide scars in the field. The landslide locations were represented using individual polygons and/or points corresponding to the scarps of the movements on the map. Field work observations of slope gradient, location, curvature and aspect were mainly undertaken to evaluate the role of topography as a conditional factor in landslide occurrence in the study area. The hillslope angle was measured using a clinometer while the width, depth (at head scarp) and length of the scars was determined by a measuring tape $(100 \mathrm{~m})$. The area of the landslides was obtained by tracking the scar using the GPS, while the measurement at the head scarp provided an estimate of mean depth of the surface of rupture of the landslide. The area and volume of each recent event was considered to represent the magnitude of the failure in consistence with Nefeslioglu et al. 2011). The landslides were classified while in the field based on the system advanced by Cruden and Varnes (1996). The old scars were, however, difficult to classify owing to the blurred shapes as a result of erosion and vegetation grown. A close scrutiny of the scars and depletion zones were made to ensure accurate mapping. The farmers bordering the old scars were interviewed to obtain supplementary information on date, extent and nature of movement.

\section{GIS data layers and data analysis}

A raster-based spatial analysis between landslide events and geomorphometric characteristics was carried out, based on Nugraha et al. (2015) and Chau et al. (2003). More precisely the landslide inventory data from the field and literature totaling to 284 records was imported into Arc GIS 10.5 for analysis of the landslide distribution and their characteristics with respect to geomorphometric parameters (slope, aspect, altitude, plan curvature). A $30 \mathrm{~m}$ SRTM DEM was obtained from USGS Earth Explorer (earthexplorer.usgs.gov) and projected to Arc 1960 UTM Zone 36 N. This was followed by filling sinks, delineating watershed and clipping out area of interest. The clipped DEM was then used to generate geomorphometric output values on slope gradient, altitude, aspect, plan curvature, profile curvature, and topographic roughness index using ArcGIS 10.5.0. The values of the slope angles derived from the STRM DEM were categorised into five classes in increments of $5^{\circ}$ (i.e. $0^{\circ}-5^{\circ}, 5^{\circ}-10^{\circ}, 11-15,16-20,21-25,26-30$ and $\left.>35^{\circ}\right)$. The values of the geomorphometric parameters were used for computation and the analyses of the significance of these values to the observed landslide pattern. According to Nefeslioglu et al. (2011) these parameters are considered to represent indirectly the pre-failure weathering conditions, strength properties and soil water contents.

The spatial relationship between landslide location and topographic parameters (slope angle, curvature, aspect) was assessed using a statistical bivariate method, the Frequency Ratio model denoted by:

$$
F R=\frac{(D i / A i)}{\left(\sum D i / \sum A i\right)}
$$

Where:

$D i=$ Number of landslides per subclass of a conditioning factor.

$A i=$ Area per subclass of conditioning factor in $\mathrm{Km}^{2}$.

$\Sigma D i=$ Total number of landslides in the study area.

$\Sigma A i=$ Total area of the study area in $\mathrm{Km}^{2}$.

The FR is the ratio of landslides in a desired class as a percentage of all landslides to the area of the class as a percentage of the entire map.

Important to note is that this methodology was utilized because all landslide scars computed were captured as GPS points rather than images that support pixel count. To harmonize this data, all conditioning factors were converted from pixel count to area in $\mathrm{Km}^{2}$ using the equations:

$$
p=\frac{\left(d^{2}\right) u}{e^{2}}
$$

Where: 
$d=30 \mathrm{~m}$ Image resolution/cell size.

$u=$ Number of pixels/cells.

$e=1000 \mathrm{~m}$, a conversion metric unit of meters to kilometers based on the metric conversion table where $1000 \mathrm{~m}=1 \mathrm{~km}$ and the vice versa (Taylor 1995).

\section{Results and discussion}

Spatial and temporal distribution pattern of landslides in the area

The spatial distribution of the past and recent landslides is shown in Fig. 3. It is evident that landslides occurrence is widely distributed in the catchment except for the area in the national park and some low lying areas in the SW and SE. However, there is observed clustering or concentration of landslides in some places and on particular slope positions. This is particularly more so for the encircled (red) areas in southern, mid-western and north western portion of the sub catchment. Regmi et al. (2014) noted that unstable areas of a landscape tend to have a cluster of landslides. They observed that landslides in the study area in Colorado are not distributed uniformly.

Another area showing a tendency of landslide concentration as observed in the field was the lower slope position adjacent the streams and rivers (Fig. 3 , bottom photographs). This reflects the undercutting action (bank erosion and incision) of the rivers particularly when there is peak runoff where sharp turnings occur and saturation by emerging sub surface flow as evidenced by streams on some depletion zones. Similarly, Broothaerts et al. (2012) in
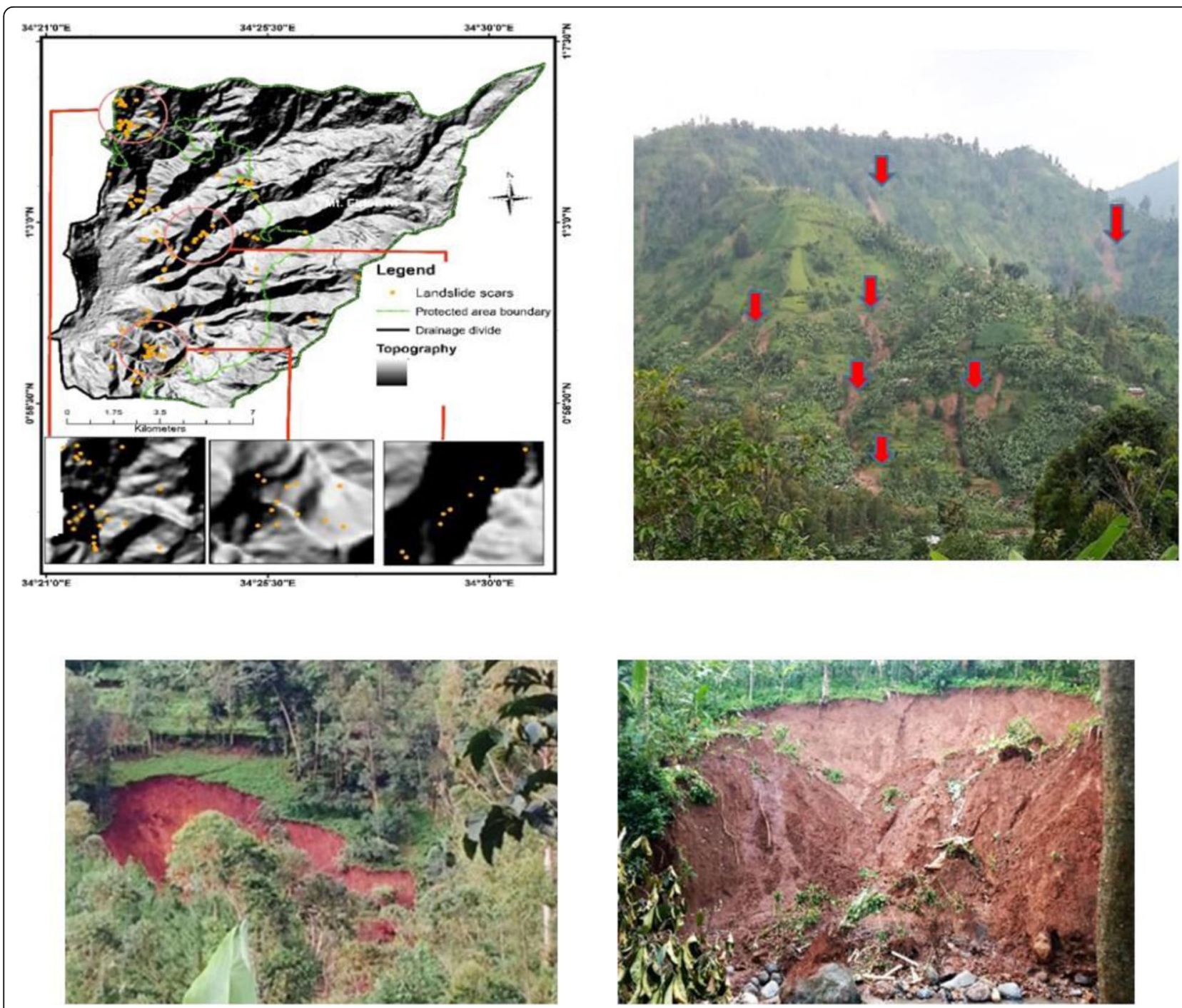

Fig. 3 Spatial distribution of landslides is illustrated in the upper left; note encircled points show concentration (irregular clustering) of landslides. Photograph on upper right corner shows landslides in Bunamwamba village; most failures occurred on mid to upper hill slope position for the June 2019 events. Lower photographs depict soil slump on the lower slope position in Buwali sub county; most of them were of small size barely exceeding $<200 \mathrm{~m}^{2}$ 
Table 1 Temporal distribution of landslides 1900-2016

\begin{tabular}{lrrr}
\hline Year & Frequency $(\mathrm{n})$ & Frequency (\%) & Cumulative frequency $(\%)$ \\
\hline$<1900$ & 16 & 3.4 & 3.4 \\
$1930-1940$ & 2 & 0.4 & 3.8 \\
$1941-1950$ & 1 & 0.2 & 4.0 \\
$1951-1960$ & 8 & 1.7 & 5.7 \\
$1961-1970$ & 6 & 1.3 & 7.0 \\
$1971-1980$ & 7 & 1.5 & 8.5 \\
$1981-1990$ & 4 & 0.9 & 9.4 \\
$1991-2000$ & 64 & 13.6 & 23.0 \\
$2001-2010$ & 111 & 23.6 & 46.6 \\
$2011-2020$ & 251 & 53.4 & 100 \\
\hline
\end{tabular}

Ethiopia observed that river incisions and bank erosion make slopes unstable, even slopes with low slope gradient.

Annual distribution pattern of landslides over the years based on the available data is depicted in Table 1 and Fig. 4 below.

There was a drastic increase from 1980 to 1990 to the current year for both the study area and the rest of the Mt Elgon. This may be attributed to increase in intensive rainfall due to climatic change. Though the area has few weather stations with longtime consistent rainfall recordings, evidence of increased rainfall frequency was observed in 2010 and 2011 by Bamutaze (2011). However, another explanation is that of growing awareness, interest and therefore recording of such events. There have been also raised concerns about the consequences as echoed in the government policy on Disaster Preparedness and Management of 2011.

\section{The diurnal and seasonal distribution of the landslides}

Response from interviewed local communities in the area revealed that most often landslides occur during the night time. In the last 5 years only two major slides occurred during day in Bumulukwani/Bunakasala at about
$2: 00 \mathrm{pm}$ (2015) and at about $1: 00 \mathrm{pm}$ in Bukalasi (Tsume) (2018). The worst occurrences in 1997/8 and 2010 in majorly Bukalasi and Nametsi occurred in the night following heavy rain downpours. Due to poor memory and lack of proper formal recordings, it is not possible to present a comprehensive account on diurnal variations of landslides in the area extending beyond a ten-year period except where linked to cultural events like circumcision. The intense rains that occurred in the night of 4th June 2019 from 6:00 pm to 10:00 pm led to numerous slope failures particularly on the mid to upper slopes in the sub counties of Buwali and Bunamambwa in Bubiita (see photograph Fig. 3 (top right). Slopes affected were moderate to steep $\left(15^{\circ}\right.$ to $\left.40^{\circ}\right)$, all cultivated and moderately settled. A few lives were lost (7 adults and 1 child of 8 years). Many homes were left at great risk on the affected slopes. The continued heavy pours were feared to induce further failures in view of the observed fragility of the slopes.

A majority of the landslides occur during the wet season thus pointing to the main triggering effect by rainfall. The peak rains occur in the second season from August to November. This is also when major slope failures occur on fragile slopes. A few failures have also taken place during the first wet season in March to May.

\section{Landslide characteristics in relation to topography}

A summary of the landslide frequency distributions in relation to the selected conditioning topographic parameters are shown in Fig. 5. The spatial distribution of the landslides with respect to the Altitude (a), slope aspect (b), slope angle (c), Plan curvature (d), Profile curvature (e) and topographic roughness (f) is further illustrated in Fig. 6 and photographs in Fig. 7 (a-d in plan curvature and hollows).

The relationship between landslides and different topographic parameters was analysed using the Frequency Ratio (FR). Table 2 presents a summary of the analyses.

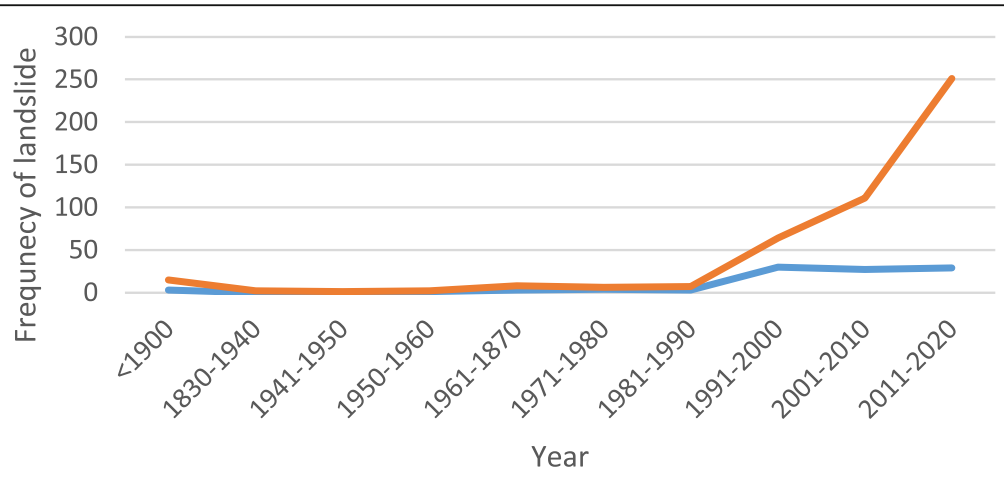

Fig. 4 Temporal landslide pattern for the study area (blue line) in comparison to the entire Mt Elgon (brown line) in eastern Uganda 


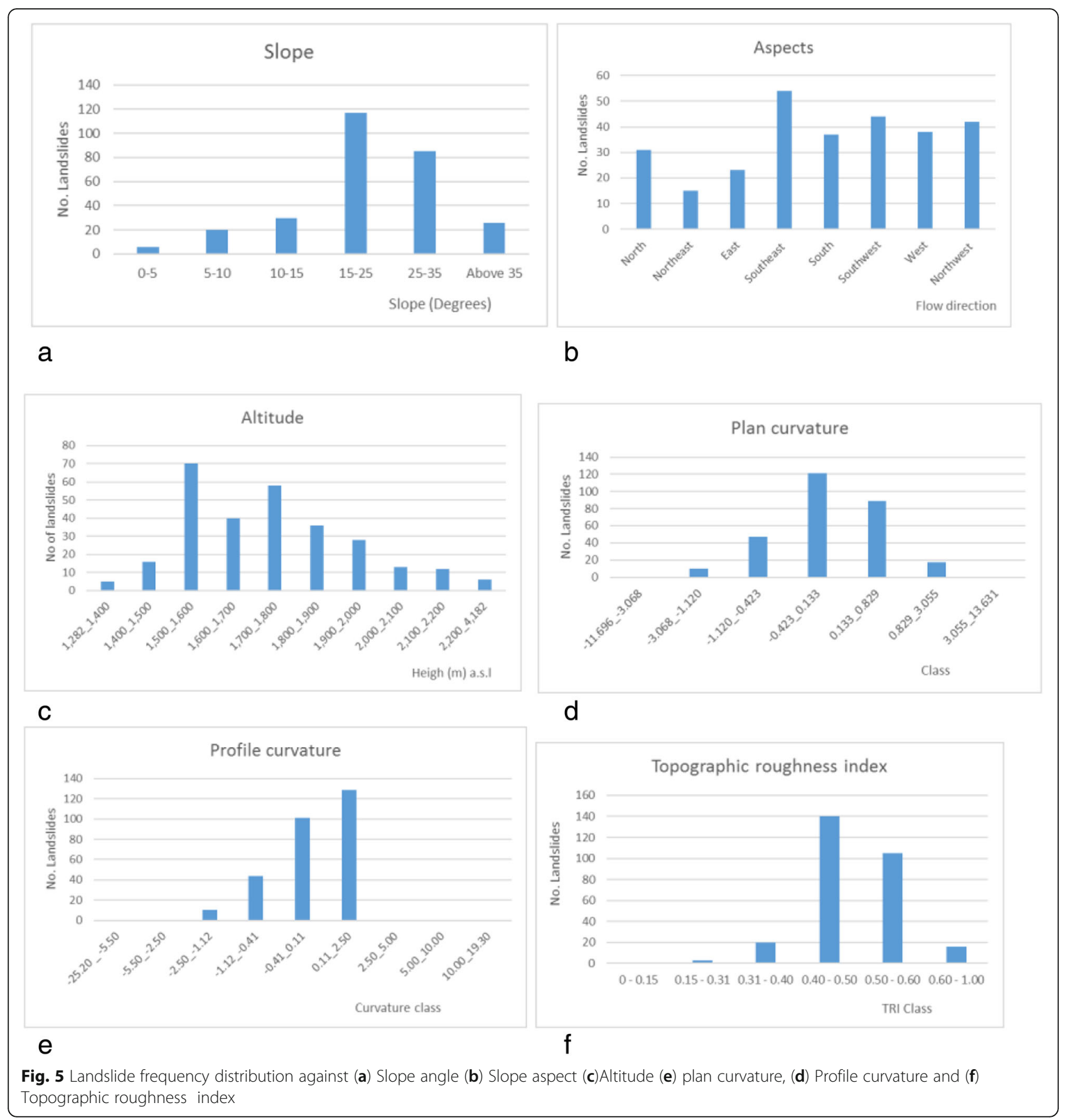

\section{Altitude}

The altitude in the catchment varies from 1200 to 2900 $\mathrm{m}$ a.s.l. There was a positive relationship from the lower altitude of $1200 \mathrm{~m}$ a.s.l. up to $1600 \mathrm{~m}$ a.s.l. then proceeded by an inverse relationship. Most of the landslides were in the mid altitude zone (1500-1800 m a.s.l. The highest Frequency Ratio (FR $=4.29$ ) was observed for the altitudinal range of $1500-1600 \mathrm{~m}$ a.s.l. This is largely attributed to increasing rainfall and therefore soil moisture with altitude. At higher altitude the shallow colluvial materials limit slide occurrences. Analysis by Bamutaze (2019) revealed that landslides were common within more or less a similar elevation of 1500 to $1800 \mathrm{~m}$ a.s.l. However, elsewhere Nugraha et al. (2015) observed higher frequency of landslides at higher elevation than lower elevation.

\section{Slope angle}

The study area was dominated by moderately steep slopes occupying $54.51 \mathrm{~km}^{2}$, which is $\sim 32 \%$ of the catchment area. As revealed in Figs. 5, 6 and Table 2 
Table 2 The spatial relationship between landslides and conditioning topographic factors with Frequency Ratio (FR)

\begin{tabular}{|c|c|c|c|c|c|c|}
\hline & No.pixel & No.Landslides (Di) & Area class km/sq. (Ai) & L.Density/class (Di/Ai) & $\sum \mathrm{Di} / \Sigma \mathrm{Ai}$ & Frequency Ratic \\
\hline \multicolumn{7}{|c|}{ Altitude (a.s.l) class } \\
\hline $1282-1400$ & 13,008 & 5 & 12.36292584 & 0.404435007 & 1.710574704 & 0.236432239 \\
\hline $1400-1500$ & 11,126 & 16 & 10.5742553 & 1.513108919 & & 0.88456173 \\
\hline $1500-1600$ & 10,047 & 70 & 9.548763524 & 7.330792078 & & 4.285572598 \\
\hline $1600-1700$ & 11,014 & 40 & 10.46780944 & 3.821238839 & & 2.23389182 \\
\hline $1700-1800$ & 14,074 & 58 & 13.37606229 & 4.336104209 & & 2.534881522 \\
\hline $1800-1900$ & 13,676 & 36 & 12.99779934 & 2.769699629 & & 1.61916321 \\
\hline $1900-2000$ & 12,112 & 28 & 11.51135899 & 2.432380053 & & 1.421966575 \\
\hline $2000-2100$ & 9303 & 13 & 8.841658909 & 1.470312317 & & 0.859542886 \\
\hline $2100-2200$ & 7758 & 12 & 7.373276343 & 1.627499017 & & 0.951434049 \\
\hline $2200-4182$ & 72,571 & 6 & 68.97216261 & 0.086991618 & & 0.050855199 \\
\hline Slope angle & No.pixel & No.Landslides (Di) & area class km/sq. (Ai) & L.Density/class (Di/Ai) & $\sum \mathrm{Di} / \Sigma \mathrm{Ai}$ & \\
\hline Very gentle & 10,206 & 6 & 9.699878623 & 0.618564441 & 1.710574704 & 0.361612059 \\
\hline Gentle & 19,837 & 20 & 18.85327182 & 1.060823829 & & 0.620156387 \\
\hline Moderate & 28,151 & 30 & 26.75497581 & 1.121286755 & & 0.655502944 \\
\hline Moderately steep & 57,364 & 117 & 54.51928643 & 2.146029555 & & 1.254566404 \\
\hline Steep & 41,468 & 85 & 39.41157816 & 2.156726626 & & 1.260819899 \\
\hline Very steep & 17,663 & 26 & 16.78708173 & 1.548809997 & & 0.905432539 \\
\hline \multicolumn{7}{|l|}{ Plan curvature } \\
\hline Curvature class & No.pixel & No.Landslides (Di) & area class km/sq. (Ai) & L.Density/class (Di/Ai) & $\sum \mathrm{Di} / \Sigma \mathrm{Ai}$ & $F R$ \\
\hline$-11.696 \_-3.068$ & 335 & 0 & 0.318387158 & 0 & 1.710574704 & 0 \\
\hline$-3.068--1.120$ & 4729 & 10 & 4.494486185 & 2.224948434 & & 1.300702289 \\
\hline$-1.120 \_-0.423$ & 24,905 & 47 & 23.66994681 & 1.985640288 & & 1.160803023 \\
\hline$-0.423 \_0.133$ & 78,682 & 121 & 74.78011462 & 1.61807722 & & 0.945926078 \\
\hline 0.133_0.829 & 54,570 & 89 & 51.86384249 & 1.716031742 & & 1.003190178 \\
\hline 0.829_3.055 & 11,110 & 17 & 10.55904875 & 1.609993514 & & 0.941200352 \\
\hline 3.055_13.631 & 358 & 0 & 0.340246575 & 0 & & 0 \\
\hline \multicolumn{7}{|l|}{ Slope Aspect } \\
\hline Bearing class & No.pixel & No.Landslides (Di) & area class km/sq. (Ai) & L.Density/class (Di/Ai) & $\sum \mathrm{Di} / \Sigma \mathrm{Ai}$ & $F R$ \\
\hline North & 17,469 & 31 & 16.6027023 & 1.867165925 & 1.710574704 & 1.091543047 \\
\hline Northeast & 6197 & 15 & 5.889687226 & 2.546824547 & & 1.488870694 \\
\hline East & 6327 & 23 & 6.013240452 & 3.824892782 & & 2.236027911 \\
\hline Southeast & 16,089 & 54 & 15.29113729 & 3.531457404 & & 2.064485927 \\
\hline South & 26,672 & 37 & 25.34932027 & 1.459605213 & & 0.707006618 \\
\hline Southwest & 31,068 & 44 & 29.52732011 & 1.490145392 & & 2.107682382 \\
\hline West & 34,179 & 38 & 32.48404384 & 1.169805095 & & 0.55501963 \\
\hline Northwest & 36,688 & 42 & 34.8686211 & 1.204521391 & & 0.704161817 \\
\hline \multicolumn{7}{|c|}{ Topographic Roughness Index } \\
\hline TRI class & No.pixel & No.Landslides (Di) & area class km/sq. (Ai) & L.Density/class (Di/Ai) & $\sum \mathrm{Di} / \Sigma \mathrm{Ai}$ & FR \\
\hline $0-0.15$ & 162 & 0 & 0.153966327 & 0 & 1.693003957 & 0 \\
\hline $0.15-0.31$ & 1968 & 3 & 1.870405754 & 1.6039301 & & 0.947387066 \\
\hline $0.31-0.40$ & 11,542 & 20 & 10.96962562 & 1.8232163 & & 1.076912001 \\
\hline $0.40-0.50$ & 80,264 & 140 & 76.28366234 & 1.8352554 & & 1.084023076 \\
\hline $0.50-0.60$ & 71,764 & 105 & 68.2051822 & 1.5394725 & & 0.909314156 \\
\hline
\end{tabular}


Table 2 The spatial relationship between landslides and conditioning topographic factors with Frequency Ratio (FR) (Continued)

\begin{tabular}{llllll}
\hline $0.60-1.00$ & 10,802 & 16 & 10.26632264 & 1.5584938 & 0.920549403 \\
Profile Curvature & No.pixel & No.Landslides (Di) & area class km/sq. (Ai) & L.Density/class (Di/Ai) & $\begin{array}{c}\text { LDi/_Ai } \\
\text { FR }\end{array}$ \\
$-25.20--5.50$ & 214 & 0 & 0.203387618 & 0 & 1.710574704 \\
$-5.50--2.50$ & 928 & 0 & 0.881979949 & 0 & 0 \\
$-2.50--1.12$ & 5334 & 10 & 5.069483889 & 1.9725874 & 1.153172315 \\
$-1.12--0.41$ & 25,179 & 44 & 23.93035899 & 1.8386686 & 1.074883552 \\
$-0.41-0.11$ & 71,679 & 101 & 68.1243974 & 1.4825819 & 0.866715682 \\
$0.11-2.50$ & 70,300 & 129 & 66.81378279 & 1.9307394 & 1.128708002 \\
$2.50-5.00$ & 822 & 0 & 0.78123655 & 0 & 0 \\
$5.00-10.00$ & 209 & 0 & 0.19863557 & 0 & 0 \\
$10.00-19.30$ & 24 & 0 & 0.022809826 & 0 & 0 \\
\hline
\end{tabular}

the moderately steep slopes $\left(15^{\circ}-25^{\circ}\right)$ had a higher FR (1.26) implying landslides were more frequent and therefore suggesting this range as a threshold. This finding is, however, in contrast to Borgomeo et al. (2014) who observed that $50 \%$ of all landslides occur on slopes between $10^{\circ}$ and $15^{\circ}$, despite this interval representing only $30 \%$ of hillslope gradients in their study area. Other researchers have found related findings. For instance, Bamutaze (2019) observed a higher frequency for slopes of $20-60 \%\left(\sim 11^{\circ}-31^{\circ}\right)$ for the entire Elgon region. Studies by Nseka et al. (2019) recorded a larger number of landslides on slopes of $25^{\circ}$ to $35^{\circ}$ in western highlands of Uganda. Bizimana (2015) observed that areas most sensitive to landslides are between slope angles above $14^{\circ}$ on convex slope and above $41^{\circ}$ on concave slopes. Depicker et al. (2018) observed slope threshold of 24.8 degrees in Democratic Republic of Congo whereas Gupta in South Africa noted that slopes of $21^{\circ}$ to $30^{\circ}$ had maximum landslide frequency. However, Zhuang et al. (2015) found that the highest density of landslides (51.81\%) was in a higher slope range of $15^{\circ}-40^{\circ}$. The slope gradient controls the shear forces acting on the hillside (Silalahi et al. 2019) and thus steeper slopes are more prone. Generally, in the current study area, the distribution of landslides was infrequent on the lower and much steeper slopes. As explained further by Zhuang et al. (2015) on lower slope gradients, the density of landslides is low because the terrain is gentle and covered with thick colluvium and/or residual soils which require higher water levels to initiate slope failures. Correspondingly, at very high slope gradients, the density of landslides is also low because the terrain is very steep with a small amount of material (e.g. colluvium) for mobilisation.

\section{Slope aspect}

Aspect can be defined as the slope direction which identifies the downslope direction of the maximum rate in change of elevation (Fernandes et al. 2004) and it is calculated in compass degrees (from -1 to 360), based on the surface tools in Arc GIS. As summarised in Table 2, a strong correlation was realized for the East $(F R=2.24)$ followed by SW $(F R=2.11)$ and SE with FR of 2.06. These terrain aspects correspond also to the direction of rainfall in the area as reported by the local population interviewed. Slope aspect can influence moisture retention and vegetation cover, which then affects soil strength and landslide occurrences (Silalahi et al. 2019).

\section{Curvature}

Two curvature values used in this study for hillslope and landslide analysis are profile and plan curvature. Profile and plan curvature affect the susceptibility to landslides. Profile curvature is the curvature in the downslope direction (aspect) along a line formed by the intersection of an imaginary vertical plane with the ground surface. Plan curvature is the curvature of the topographic contours or the curvature of a line formed by the intersection of an imaginary horizontal plane with the ground surface. Profile curvature affects the driving and resisting stresses within a landslide in the direction of motion. Plan curvature controls the convergence or divergence of landslide material and water in the direction of landslide motion (Carson and Kirkby, 1972 cited by Ohlmacher 2007; De Rose 2013).

As shown in Table 2, the values of curvature were classified into three classes of surfaces, that is, concave, planar, and convex. Positive values of curvature are concave in a downslope direction or hollows. Most of the slides in this study area were in planar then followed by concave (hollow) regions of the hillslopes (Fig. 7b-e). The planar curvature category 3.068-1.120 had the highest FR of 1.30 implying its greater influence on landslide occurrence. This is consistent with Ohlmacher (2007) observation that 

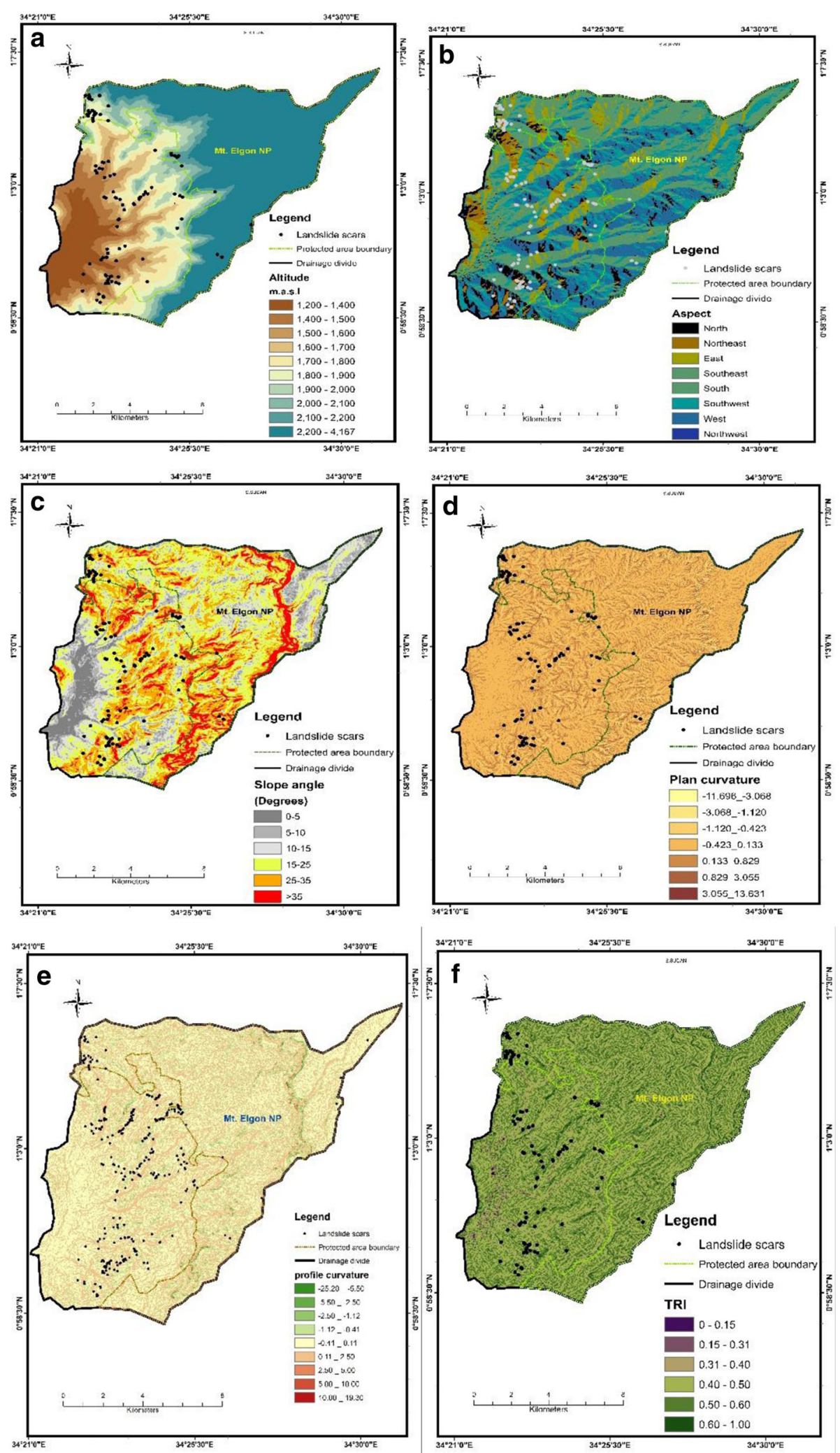

Fig. 6 Landslide distribution against slope angle (a), Altitude (b), Slope aspect (c), Slope angle (d), Plan curvature (e) Profile curvature (f) Topographic roughness index 

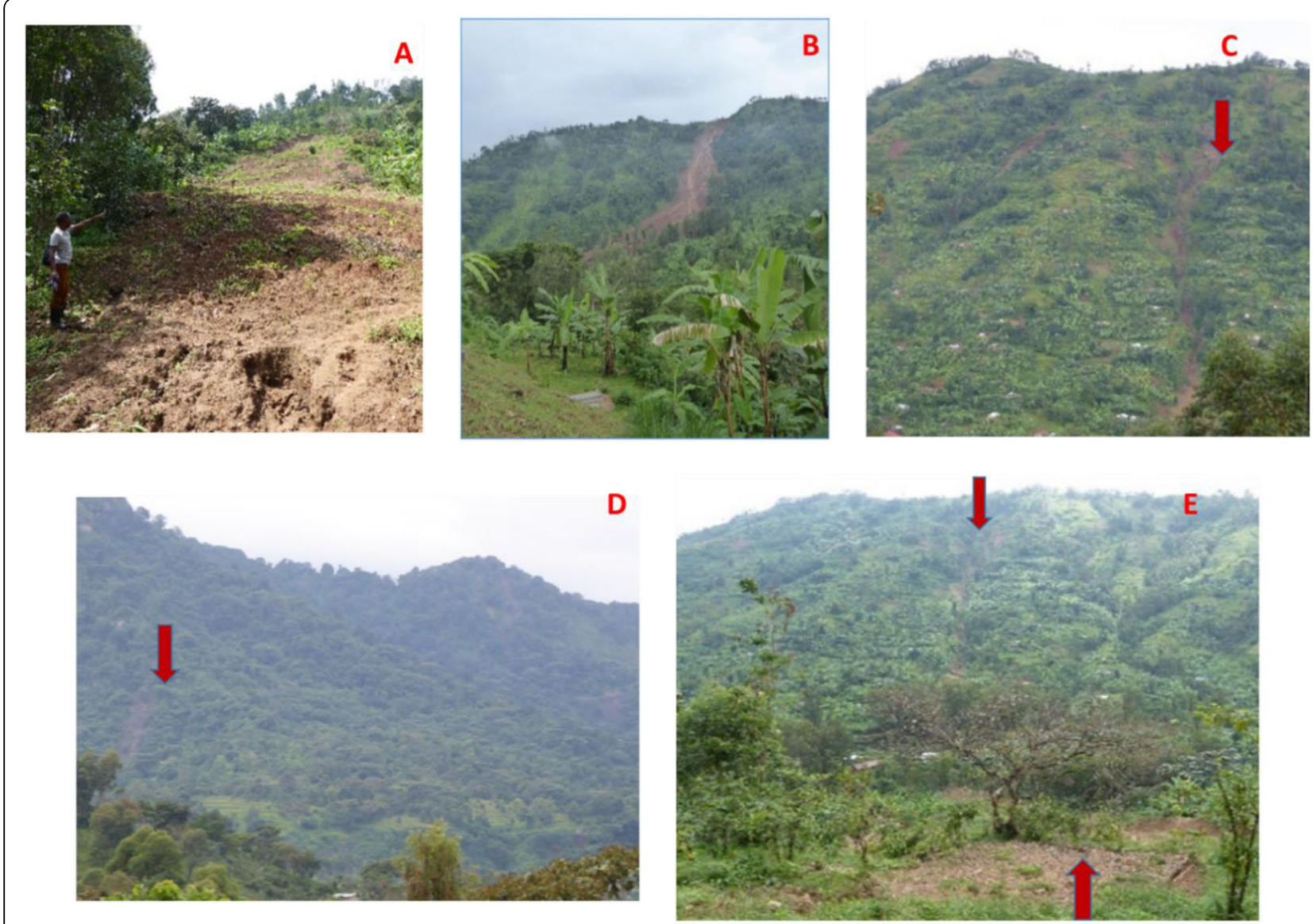

Fig. 7 Distribution of landslides on varied topography (a) debris flow in Bunamwamba village (b) Earth flow in Buwali village (c) soil slips in forest (d) complex slide/flow (e) Complex slides on two opposite hillslopes plan and hollow curvature slope in Bunamwamba and Buwali villages

planar plan curvature has the highest probability for landslides in regions dominated by earth flows and earth slides in clayey soils. Zhuang et al. (2015) also observed that landslide occurrences are abundant at locations with convex (40.96\%) and concave surfaces (36.75\%) in the Qin Mountain, with planar surfaces (42.86\%) in the Li Mountain, and convex (40.82\%) and planar $(34.70 \%)$ surfaces in the Loess Tableland. Regmi et al. (2014) observed that debris flows mostly occur in areas of topographic convergence covered by unconsolidated deposits, whereas debris slides mostly occur in planar and concave slopes covered by unconsolidated alluvium and colluvium. Rock slides mostly occur in steep and convex to planar slopes. Soil slides were all over but in smaller sizes in the study area.

For profile curvature the category belonging to -2.50 to -1.12 had the highest FR (1.15) followed closely by 0.11 to 2.30 with $\mathrm{FR}=1.13$.

To evaluate the slope curvature, another curvature parameter, namely the convergence index, was also taken into account. Oloya (2004) noted that the convergence index is a more practical parameter for visually evaluating the slope curvature. Regmi et al. (2014) found that small and medium sized landslides occurred on convergent and divergent slopes whereas the large landslides were on planar parts of slopes.

\section{Topographic Roughness Index (TRI)}

The topographic roughness index (TRI) expresses the amount of elevation difference between adjacent cells of a DEM. TRI is considered as a morphometric measure, which describes the heterogeneity of a land surface; it characterizes the terrain as smooth, rugged landforms. The results (Table 2) showed that the terrain roughness indices $0.31-0.40$ and $0.40-0.50$ had the highest density of landslides (1.82 and 1.83) and FR of 1.07 and 1.08 respectively. Regmi and Walter (2019) also recorded high roughness values in landslide surfaces including scarps and deposits, and undulated surface topography developed by soil creeps plus areas with rills, gullies, incised first and higher order channels, ridges, and spurs. 


\section{Implications of landslide pattern and distribution on risk management}

As explained above, quite a number of failures were observed on mid to upper slope positions either coinciding with or close to the previous scars. Some of the mid to lower slope positions experienced depositions with long runout distances measuring over $80 \mathrm{~m}$. Therefore, greater attention should be directed to such slope positions and more particularly to prevalent conditions at ridge top. Field observations revealed high surface runoff generation from iron sheet roofed houses, compounds and gardens. High surface runoff from ridge tops contributes to rapid buildup of pore pressure due to infiltration on upper slopes. This needs to be urgently controlled through harvesting and proper directing to streams downslope. Anderson et al. (2011) emphasizes this approach to local surface runoff as being effective in reducing landslide risk in the Caribbean. Concerted efforts should also involve collaboration of farming communities along the entire hillslopes and catchment as a whole.

Hillslope forms particularly the convex shaped (hollows) should be used cautiously since they are susceptible to land sliding. Related caution was also sounded by Fernandes et al. (2004). A suitable practice is to reserve such areas or sites for conservation agriculture; low intensive land use with minimal soil disturbance. For instance, dedicating such areas under orchard farming.

Ecological restoration of previous scars, be it on lower or mid-upper slopes, is required in order to enhance the slope stability. An appropriate greening strategy is desirable. Planting of common trees such as Eucalyptus species (e.G. eucalyptus grandis) is on its own not sufficient intervention as evidenced by recent debris flows in woodlots. A careful selection of trees including those with deep and strong tensile roots is paramount. Deep roots contribute to anchoring top and sub soils with regolith.

Settlements built in the pathways of landslides on slopes is dangerous due to associated uncertainties and therefore inhabitants should be compelled to relocate to safer areas in nearby places. Quite often such housing construction contributes to higher surface runoff generation and also entail slope cutting which undermines stability. This is more so where settlements are within or located close to hollow and concave slope shapes.

\section{Conclusion}

This study set out to investigate the topographic influence on the pattern and spatio-temporal distribution of landslides, and implications on risk management in the selected upper catchment of R. Manafwa. The landslide database was constructed from the field surveys coupled with review of previous research works. The data was analysed using Arc GIS 10.5 and Frequency Ratio model. The results reveal that the landslides are generally unevenly distributed over the study area. Four sites, however, displayed close distribution or clustered landslides. Evidence suggest topographic attributes have a major influence on the spatial and temporal distribution of the landslides. Moderate slopes of $15^{\circ}-25^{\circ}$ were most influential in landslide occurrences. Slope plan curvature (3.068-1.20) exhibited a significant relationship with landslide occurrence as revealed by a high frequency of 1.30. Overall landslides were repetitive, that is majorly limited to depressions (hollows) and plan curvature on or in close proximity of old scars. Occurrence of landslides on upper slope position was attributed to increased surface runoff from gardens, compounds and roof tops on ridge tops. Therefore, strategies designed to mitigate risks due to slope failures should not ignore topographic attributes (slope angle, curvature) besides ensuring safe disposal of surface runoff and enhancing green solutions for such areas with high fragility.

\section{Acknowledgements}

We are very grateful to our research assistants Mr. Kutosi Moses and Mr. Yeeko Isaac for enduring the tough climbing while collecting the data and mapping of the landslide scars. The local communities and partners were very cooperative during field surveys.

\section{Authors' contributions}

BN, was responsible for conceptualization, writing, interpretation and quality control. SN, was in charge of data capture and GIS analysis. The author(s) read and approved the final manuscript.

\section{Funding}

This research would not be possible without the generous support from The Swedish International Development Agency (Sida) -Makerere University under the BREAD project 331.

\section{Availability of data and materials}

The data set used/not used for analysis in this paper are available on request from the corresponding author.

\section{Competing interests}

The authors declare no conflict of interest.

Received: 2 March 2020 Accepted: 24 July 2020

Published online: 24 September 2020

\section{References}

Anderson MG, Holcombe E, Blake JR, Ghesquire F, Holm-Nielsen N, Fisseha T (2011?2010) Reducing landslide risks in communities: evidence from the Caribbean. Appl Geog 31:590-599

Ayonghe SN, Ntasin EB (2003) The geological control and triggering mechanisms of landslides of 20th July 2003 within the Baboutos Caldera, Cameroon. J of the Cameroon Academy of Sc 7;(3):191-204

Bagoora FDK (1993) An assessment of some cases and effects of soil erosion hazards in Kabale highland, south-western Uganda, and people's attitude towards conseravtion. In: Bencherifa A (Ed.) Resource Use and Conservation; Faculty of Social Sciences, Mohammed U University, Rabat. Morocco, pp $215-236$

Bamutaze Y (2011) Patterns of water erosion and sediment loading on Mt. Elgon, eastern Uganda. PhD. Makerere University, Kampala, Uganda

Bamutaze Y (2019) Morphometric conditions underpinning the spatial and temporal dynamics of landslide hazards on the volcanics of Mt. Eastern 
Uganda. Emerging Voices in Natural Hazards Research, Elgon. https:/doi.org/ 10.1016/B978-0-12-815821-0.00010-2

Bizimana H (2015) Landslide occurrences in the hilly areas of Rwanda, their causes and protection measures. Disaster Sci Eng 1(1):1-7

Borgomeo E, Hebditch KV, Whittaker AC, Lonergan L (2014) Characterising the spatial distribution, frequency and geomorphic controls on landslide occurrence, Molise, Italy

Broothaerts N, Kissi E, Poesen J, Van Rompaey A, Getahun K, Van Ranst E, Diels J (2012) Spatial patterns, causes and consequences of landslides in the Gilgel gibe catchment, SW Ethiopia. Catena 97(2012):127-136

Chau KT, Sze YL, Fung MK, Wong WY, Fong EL, Chan LCP (2003) Landslide hazard analysis for HongKongusing landslide inventory and GIS. Comput Geosci 30(2004):429-443

Claessens L, Knapen A, Kitutu MG, Poesen J, Deckers JA (2007) Modelling landslide hazard, soil redistribution and sediment yield of landslides on the Ugandan footslopes of Mount Elgon. Geomorphology 90(1-2):23-35. https:// doi.org/10.1016/j.geomorph.2007.01.007

Cruden DM, Varnes DJ (1996) Landslide types and processes. Special Report, Transp Res Board 247:36-75

Dahl MPJ, Mortensen LE, Jensen NH, Veihe A (2011) Magnitude-frequency characteristics and preparatory factors for spatial debris-slide distribution in the northern Faroe Islands. Geomorphology 188(2013):3-11

Davies TC (1996) Landslide research in Kenya. J Afr Earth Sc 23(4):541-545

De Rose RC (2013) Slope control on the frequency distribution of shallow landslides and associated soil properties, North Island, New Zealand. Earth Surf Process Landforms 38:356-371

Depicker A, Govers G, Van Rompaey A, Havenith HB, Mateso JCM, Demitte O (2018) Landslides in a changing tropical environment: North Tanganyika-Rift Kivu zones. https://www.researchgate.net/publication/325176935

Fernandes NF, Guimarães RF, Gomes RAT, Vieira BC, Montgomery DR, Greenberg H (2004) Topographic controls of landslides in Rio de Janeiro: field evidence and modeling. CATENA 55(2004):163-181

Giuseppe F, Simoni S, Godt JW, Lu N, Rigon R (2016) Geomorphological control on variably saturated hillslope hydrology and slope instability. Water Resour Res 52:4590-4607. https://doi.org/10.1002/2015WR017626

Gupta (2001) Geomorphological controls on landslide activity in Du Totios Kroof, Western Cape Mountain, South Africa. S Afr Geogr I 83(3):258-263

Kervyn M.L., Jacobs, J. Maes, V. Bih Che, A. de Hontheim, O. Dewitte, M. Isabirye, J. Sekajugo, C. Kabaseke, J. Poesen, L. Vranken and K. Mertens, « Landslide resilience in Equatorial Africa: Moving beyond problem identification! », Belgeo [Online], 1 | 2015, Online since 30 June 2015, connection on 30 September 2016. URL: http://belgeo.revues.org/15944; https://doi.org/10.4000/belgeo.15944

Kimaro DN, Msanya BM, Kilasara M, Mtakwa PW, Poesen J, Deckers JA (2000) Major factors influencing the occurrence of landslides in the northern slopes of the Uluguru Mountains, Tanzania

Kitutu MG (2010) Landslide occurrences in the hilly areas of Bududa district in eastern Uganda and their causes. PhD Thesis, Makerere University.

Kitutu MG, Poesen GM, Deckers JM (2011) Farmers perceptions on landslide occurrences in Bududa district, eastern Uganda. Afr J Agr Res 6:7-18

Knapen A, Kitutu MG, Poesen J, Breugelmans W, Deckers J, Muwanga A (2006) Landslides in a densely populated county at the footslopes of mount Elgon (Uganda): characteristics and causal factors. Geomorphology 73:149-165

Mertens K, Jacobs L, Maes J, Kabaseke C, Maertens M, Poesen J, Kervyn M, Vranken $L$ (2016) The direct impact of landslides on household income in tropical regions: A case study from the Rwenzori Mountains in Uganda. Sc Total Environ 550:1032-1043. https://doi.org/10.1016/j.scitotenv.2016.01.171

Monsieurs E, Kirschbaum DB, Thiery W, van Lipzig N, Kervyn M, Demoulin A Jacobs L, Kervyn F, Dewitte O (2017) Constraints on landslide-climate research imposed by the reality of fieldwork in Central Africa. Association of Environmental \& Engineering Geologists (AEG). Third North American Symposium on Landslides. https://orbi.uliege.be/bitstream/2268/213093/1/ Monsieurs\%20et\%20al\%202017\%20NASL.pdf

Mugagga F, Kakembo V, Buyinza M (2012) Land use changes on the slopes of mount Elgon and the implications for the occurrence of landslides. CATENA 90:36-46. https://doi.org/10.1016/j.catena.2011.11.004

Mwaniki MW, Agutu NO, Mbaka JG, Ngigi TG, Waithaka EH (2015) Landslide scar/soil erodibility mapping using Landsat TM/ETMp bands 7 and 3 Normalised Difference Index: A case study of central region of Kenya. Appl Geogr 64:108e120

Nefeslioglu HA, Gokceoglu C, Sonmez H, Gorum T (2011) Medium-scale hazard mapping for shallow landslide initiation: the Buyukkoy catchment area (Cayeli, Rize, Turkey). Landslides. https://doi.org/10.1007/s10346-011-0267-7
Ngecu W, Nyamai C, Erima G (2004) The extent and significance of massmovements in Eastern Africa: Case studies of some major landslides in Uganda and Kenya. Environ Geol 46:1123-1133. https://doi.org/10.1007/ s00254-004-1116-y.

Ngecu WM, Ichang DW (1999) The environmental impact of landslides on the population living on the eastern footslopes of the Aberdare ranges in Kenya: a case study of Maringa Village Landslide Environmental Geology 38(3):259-264

Nguimbous-Kouoh JJ, Manguelle-Dicoum E (2010) Contribution of topographic and penetrometric measurements to a site characterization, case of the Kekem Landslide, National Road №5 (Western Cameroon). Earth Sci Res S J 14(2):135-144

Nugraha H, Wacano D, Dipayana GA, Cahyadi A, Mutaqinc BW, Larasati A (2015) Geomorphometric characteristics of landslides in the Tinalah watershed, Menoreh Mountains, Yogyakarta, Indonesia. Procedia Environ Sci 28(2015): 578-586

Nseka D, Kisembo V, Yazidhi Y, Mugagga F (2019) Analysis of topographic parameters underpinning landslide occurrence in Kigezi highlands of south western Uganda. Natural Hazards 99(2):976-989. https://doi.org/10.1007/ s11069-019-03787-x

Ohlmacher GC (2007) Plan curvature and landslide probability in regions dominated by earth flows and earth slides. Eng Geol 91(2007):117-134. https://doi.org/10.1016/j.enggeo.2007.01.005

Oloya V (2004) A gentle introduction to SAGA GIS. Available from http:// downloads.sourceforge.net/saga-gis/SagaManual.pdf. Accessed 15 Feb 2020

Regmi NR, Giardino JR, McDonald EV, Vitek JD (2014) A comparison of logistic regression-based models of susceptibility to landslides in western Colorado, USA. Landslides 11:247-262. https://doi.org/10.1007/s10346-012-0380-2

Regmi NR, Walter II (2019) Detailed mapping of shallow landslides in eastern Oklahoma and western Arkansas and potential trigge..., Geomorphology, https://doi.org/10.1016/j.geomorph.2019.05.026

Silalahi FES, Arifianti PY, Hidayat F (2019) Landslide susceptibility assessment using frequency ratio model in Bogor, West Java, Indonesia. Geosci Lett 6:10. https://doi.org/10.1186/s40562-019-0140-4

Taylor B (1995) Guide for the use of the International System of Units (SI): The metric system. DIANE Publishing Co..Darby PA, USA. ISBN 0788125796, 9780788125799

Temple PH, Rapp A (1972) Landslides in the Mgeta area, western Uluguru mountains, tanzania Geomorphological effects of sudden heavy rainfall. Geografiska Annaler 54 A:3-4

Westerberg L-O, Christiansson C Highlands in East Africa: Unstable Slopes, Unstable Environments? Ambio 28(5) Research for Mountain Area Development: Africa and Asia (Aug., 1999):419-429

Zhuang J, Peng J, lqbal J, Liu T, Liu N, Li Y, MA P (2015) Identification of landslide spatial distribution and susceptibility assessment in relation to topography in the Xi'an Region, Shaanxi Province, China. Front Earth Sci 9(3):449-462. https://doi.org/10.1007/S11707-014-0474-3

Zogning A, Ngouanet C, Tiafack O (2007) The catastrophic geomorphological processes in humid tropical Africa: A case study of the recent landslide disasters in Cameroon. Sediment Geol 199(2007):13-27

\section{Publisher's Note}

Springer Nature remains neutral with regard to jurisdictional claims in published maps and institutional affiliations.

\section{Submit your manuscript to a SpringerOpen ${ }^{\circ}$ journal and benefit from:}

- Convenient online submission

- Rigorous peer review

- Open access: articles freely available online

High visibility within the field

- Retaining the copyright to your article

Submit your next manuscript at $\boldsymbol{\nabla}$ springeropen.com 